\title{
Erratum to uniportal video-assisted thoracic surgery, and the uni-surgeon: new words for the contemporary world
}

\section{Editorial Office}

Journal of Visualized Surgery

Correspondence to: Editorial Office. Journal of Visualized Surgery. Email: jovs@amepc.org

Received: 05 June 2018; Accepted: 27 June 2018; Published: 30 June 2018

doi: 10.21037 /jovs.2018.06.18

View this article at: http://dx.doi.org/10.21037/jovs.2018.06.18

Erratum to: J Vis Surg 2018;4:45.

Uniportal video-assisted thoracic surgery, and the uni-surgeon: new words for the contemporary world

In the article entitled "Uniportal video-assisted thoracic surgery, and the uni-surgeon: new words for the contemporary world" on 07 March 2018 (1), there were two typos in the Table 1 [in the first line, reference after author "Gonzalez-Rivas" should be (4) instead of (3), year of publication should be 2011 instead of 2003].

This article was updated to correct the Table 1 as following:

Table 1 Evidence table: reduced length of skin incision to perform uniportal video-assisted thoracic surgery (U-VATS) anatomical lung resection

\begin{tabular}{|c|c|c|c|c|}
\hline Author & Year of publication & Type of resection & \multicolumn{2}{|c|}{ Length of the skin incision } \\
\hline Gonzalez-Rivas (4) & 2011 & Lobectomy & 5.0 & - \\
\hline Wang (8) & 2015 & Lobectomy/segmentectomy & 4.0 & - \\
\hline Ocakcioglu (9) & 2015 & Lobectomy & 3.0 & - \\
\hline Liu (11) & 2014 & Lobectomy & 0 & $5 \mathrm{~cm}$ sub-xiphoid \\
\hline Zieliński (12) & 2007 & Lobectomy & 0 & 5-9 cm transcervical \\
\hline
\end{tabular}

The publisher regrets the error.

Open Access Statement: This is an Open Access article distributed in accordance with the Creative Commons AttributionNonCommercial-NoDerivs 4.0 International License (CC BY-NC-ND 4.0), which permits the non-commercial replication and distribution of the article with the strict proviso that no changes or edits are made and the original work is properly cited (including links to both the formal publication through the relevant DOI and the license). See: https://creativecommons.org/licenses/by-nc$\mathrm{nd} / 4.0 /$. 
Page 2 of 2

\section{References}

1. Migliore M. Uniportal video-assisted thoracic surgery, and the uni-surgeon: new words for the contemporary world. J Vis Surg 2018;4:45.

doi: $10.21037 /$ jovs.2018.06.18

Cite this article as: Editorial Office. Erratum to uniportal video-assisted thoracic surgery, and the uni-surgeon: new words for the contemporary world. J Vis Surg 2018;4:127. 